\title{
Prediksi Akhir Pandemi COVID-19 di Indonesia dengan Simulasi Berbasis Model Pertumbuhan Parametrik
}

\author{
Fransiscus Rian Pratikto \\ Fakultas Teknologi Industri, Jurusan Teknik Industri, Universitas Katolik Parahyangan \\ Jl. Ciumbuleuit 94, Bandung 40141 \\ Email: frianp@unpar.ac.id
}

\begin{abstract}
This research aims to predict the end of the COVID-19 pandemic in Indonesia based on parametric growth models. The models are chosen by considering their fitness with the data of Taiwan which is believed to have passed over the peak of the pandemic and have gone through all phases in the growth curves. The models are parameterized using the nonlinear least squares method. The deviation and confidence interval of each parameter is estimated using the $k$-fold cross-validation and the bootstrap techniques. Using the total cases per million population data from March 2 to June 18,2020 , it was found that two growth models fit the data, i.e. logistic and modified Gompertz, where the latter performs better. Using the information about the deviation of each model parameter, a simulation model is developed to predict the time at which the total cases curve starts to flatten, which is an indication of the end of the pandemic. It was found with $95 \%$ confidence level that based on the modified Gompertz model the pandemic will end somewhere between March 9 - September 7, 2021 with total cases per million of 206 - 555. Meanwhile, based on the logistic growth model, the end of the pandemic is between August 28 - September 23, 2020 with total cases per million of 180 - 375. This model can be extended by making comparative scenario with Taiwan based on measures that represent the quality of the pandemic mitigation such as test ratio and the intensity of social restriction.
\end{abstract}

Keywords: COVID-19, modified Gompertz, nonlinear least squares, parametric growth model

\begin{abstract}
Abstrak
Penelitian ini bertujuan memprediksi akhir pandemi COVID-19 di Indonesia berdasarkan model pertumbuhan parametrik. Beberapa model dipilih berdasarkan kesesuaiannya dengan data Taiwan yang dianggap sebagai negara yang telah melewati puncak pandemi dan telah mengalami semua fase pertumbuhan. Model pertumbuhan diestimasi menggunakan metode nonlinear least squares. Simpangan dan selang kepercayaan untuk setiap parameter model diestimasi menggunakan metode $k$-fold cross validation dan bootstrap. Dengan menggunakan data total kasus per sejuta penduduk dari 2 Maret sampai dengan 18 Juni 2020, diperoleh dua model pertumbuhan yang sesuai dengan data Indonesia, yaitu logistik dan modified Gompertz, di mana model modified Gompertz memiliki kesesuaian yang lebih tinggi. Dengan menggunakan informasi mengenai simpangan nilai setiap parameter, dibuat model simulasi untuk memprediksi saat kurva total kasus mulai melandai, yang merupakan indikasi akhir pandemi. Dari hasil simulasi dengan tingkat keyakinan $95 \%$ didapati bahwa menurut model modified Gompertz pandemi akan berakhir antara 9 Maret - 7 September 2021 pada level total kasus per sejuta penduduk antara 206 sampai dengan 555. Sementara itu, menurut model logistik, pandemi akan berakhir antara 28 Agustus - 23 September 2020 pada level total kasus per sejuta penduduk antara 180 sampai 375 . Penelitian ini dapat dikembangkan dengan membuat skenario perbandingan dengan Taiwan berdasarkan ukuran yang merepresentasikan kualitas penanganan pandemi seperti rasio tes dan intensitas pembatasan sosial.
\end{abstract}

Kata kunci: model pertumbuhan parametrik, modified Gompertz, nonlinear least squares, COVID19 


\section{Pendahuluan}

Sejak pertama kali kasus infeksi COVID19 secara resmi diakui dan dicatat di Indonesia pada 2 Maret 2020, pertambahan kasus baru belum menunjukkan indikasi melandai. Berdasarkan data dari Our World in Data (Roser, 2020) per 18 Juni 2020, total kasus per sejuta penduduk Indonesia adalah sebesar 151,47 dengan rerata kasus baru selama 14 hari terakhir sebesar 3,45 per sejuta penduduk. Statistik yang sama untuk Taiwan, sebagai negara yang diyakini telah berhasil mengatasi pandemi, per 18 Juni 2020 adalah 18,68 untuk total kasus dan tidak ada pertambahan kasus baru.

Pertambahan kasus baru yang relatif masih tinggi mengindikasikan bahwa Indonesia belum melewati puncak pandemi. Dalam kondisi seperti ini, pertanyaan yang penting untuk dicari tahu jawabannya oleh pengambil keputusan (Pemerintah) adalah kapan dan pada tingkat total kasus berapa pandemi COVID-19 akan berakhir.

Beberapa model telah dibangun untuk merepresentasikan pandemi COVID-19, mulai dari model time series berbasis model pertumbuhan seperti dalam Nuraini et al. (2020) dan Shen (2020), model stokastik berbasis model kompartemental SEIR (Kermack \& McKendrick, 1927) seperti dalam Fang et al., (2020), sampai model white box berbasis system dynamics seperti dalam Vega (2020). Model pertumbuhan time series bertitik tolak dari asumsi bahwa pada akhirnya pertambahan kasus akan dibatasi oleh banyaknya populasi yang rentan tertular karena orang yang pernah tertular dan sembuh akan memperoleh imunitas dalam tubuhnya (Halloran, 2001). Ini berarti bahwa terlepas dari apa pun yang dilakukan untuk menangani pandemi, pertambahan kasus pada akhirnya akan melandai. Jika variabel status yang digunakan adalah total kasus, intervensi yang dilakukan diasumsikan tidak akan mempengaruhi level total kasus ketika kondisi akhir tercapai, tapi akan mempengaruhi kapan tercapainya.

Model-model berbasis kompartemental dan system dynamics umumnya mengaitkan ukuran-ukuran penularan penyakit dengan berbagai variabel anteseden dan intervensi. Fang et al. (2020) menggunakan parameter yang merepresentasikan tingkatan intervensi di mana skor yang lebih tinggi diberikan untuk upaya-upaya yang bertujuan mencegah penyebaran virus. Sementara itu, Vega (2020) menggunakan bentuk pembatasan sosial dan tingkat efektivitas sebagai variabel intervensi. Model-model seperti ini umumnya fokus untuk menentukan intervensi yang paling tepat untuk mengatasi pandemi.

Penelitian ini bertujuan memprediksi akhir pandemi COVID-19 di Indonesia yang dikarakterisasi dengan kurva total kasus yang melandai yang identik dengan pertambahan kasus baru yang relatif rendah. Karena tidak ada batasan baku mengenai dua kondisi ini, dilakukan perbandingan dengan negara yang diyakini telah mencapai akhir pandemi, yaitu Taiwan. Variabel status yang digunakan untuk kondisi akhir pandemi adalah total kasus per sejuta penduduk. Model time series yang digunakan dipilih berdasarkan model yang sesuai untuk Taiwan. Empat model pertumbuhan akan dicoba, yaitu model logistik, Richards, modified Gompertz, dan expanded Gompertz. Estimasi dilakukan menggunakan metode nonlinear least squares (Bates \& Chambers, 1991). Selanjutnya, selang kepercayaan 95\% untuk semua parameter diestimasi menggunakan validasi silang (Bates \& Watts, 2007) dan bootstrap (Efron \& Tibshirani, 1993).

\section{Metodologi}

Model pertumbuhan yang dicoba untuk memodelkan pertumbuhan penularan COVID19 dalam penelitian ini adalah model logistik, modified Gompertz, dan Richards yang mengacu pada Zwietering et al. (1990), dan expanded Gompertz yang mengacu pada Kahm et al. (2010). Misalkan $y(t)$ adalah variabel yang ingin dimodelkan pertumbuhannya, dalam hal ini adalah total kasus per sejuta penduduk. Model logistik yang digunakan dalam penelitian ini mengikuti formula berikut (Zwietering et al., 1990):

$$
y(t)=\frac{A}{1+e^{\left(\frac{4 \mu}{A}(\lambda-t)+2\right)}} \quad \text { Pers. } 1
$$

Model ini memiliki 3 parameter, yaitu $A$ yang merepresentasikan nilai maksimum yang mungkin dicapai $y(t), \mu$ merepresentasikan laju pertumbuhan maksimum, dan $\lambda$ merepresentasikan interval waktu sebelum pertumbuhan terjadi (lag phase). 
Model Richards merupakan bentuk umum dari fungsi logistik (generalized logistic function). Model ini dikembangkan pertama kali oleh F.J. Richards (Richards, 1959). Model Richards yang digunakan dalam penelitian ini mengacu pada Zwietering et al. (1990) dengan formula sebagai berikut:

$$
y(t)=\frac{A}{\left.\left[1+v e^{\left(1+v+\frac{\mu}{A}(1+v)\left(1+\frac{1}{v}\right)\right.}(\lambda-t)\right)\right]^{\frac{1}{v}}} \text { Pers. 2 }
$$

Dibandingkan fungsi logistik, fungsi Richards memiliki satu parameter tambahan yaitu $v$ yang memberikan fleksibilitas posisi inflexion point dalam kurva pertumbuhan. Model modified Gompertz yang digunakan adalah sebagai berikut (Zwietering et al., 1990):

$$
y(t)=\frac{A}{e^{e^{\left(\frac{\mu e}{A}(\lambda-t)+1\right)}}}
$$

Pers. 3

Model ini memiliki 3 parameter dengan interpretasi yang sama dengan model logistik, namun sedikit berbeda dalam hubungan matematisnya.

Terdapat kerancuan dalam penggunaan istilah modified Gompertz. Model di persamaan 3 oleh Zwietering et al. (1990) disebut sebagai modified Gompertz, sementara dalam Kahm et al. (2010) model di persamaan 3 disebut sebagai model Gompertz. Penelitian ini mengikuti istilah dalam Zwietering et al. (1990).

Model expanded Gompertz adalah model yang dalam Kahm et al (2010) disebut sebagai modified Gompertz. Model ini mengakomodasi kemungkinan adanya fase pertumbuhan kedua setelah fase pertumbuhan pertama mencapai tingkat jenuh. Model memiliki formula sebagai berikut (Kahm et al., 2020):

$$
y(t)=\frac{A}{e^{\left[e^{\left[\frac{\mu e}{A}(\lambda-t)+1\right)}\right]}}+A e^{\alpha\left(t-t_{s}\right)}
$$

Pers. 4

Dibandingkan model modified Gompertz, model expanded Gompertz memiliki 2 parameter tambahan, yaitu $\alpha$ yang merepresentasikan laju pertumbuhan fase kedua, dan $t_{s}$ yang merepresentasikan faktor skala dari sumbu horizontal (waktu).

Estimasi model pertumbuhan dalam penelitian ini dilakukan dengan metode nonlinear least squares (NLS) yang menggunakan algoritma Gauss-Newton untuk mendapatkan solusi (Bates \& Chambers, 1991). Dalam proses iteratif ini, nilai residual dan gradien dihitung untuk setiap set nilai parameter. Faktor perubahan (increment) nilai parameter diperoleh dengan menerapkan linear least squares pada residual terhadap gradien. Jika perubahan penuh semua parameter menyebabkan nilai jumlah kuadrat meningkat, maka perubahan parameter ditentukan hanya setengahnya saja. Sementara itu, time-step secara umum ditentukan dengan dua kali lipat nilai yang berhasil menurunkan jumlah kuadrat dalam iterasi sebelumnya.

Estimasi tingkat galat dan selang kepercayaan untuk setiap parameter diestimasi menggunakan validasi silang dan bootstrap nonparametrik. Validasi silang (Bates \& Watts, 2007) dilakukan dengan membagi sampel menjadi $K$ sub sampel yang mutually exclusive. Selanjutnya, untuk setiap sub sampel $k=$ $1, \ldots, K, K-1$ sub sampel digunakan untuk mengestimasi parameter model yang hasilnya kemudian dibandingkan dengan hasil estimasi parameter dari sub sampel $k$. Tingkat galat untuk setiap parameter kemudian dihitung untuk setiap sub sampel $k$, dan digunakan untuk membentuk selang kepercayaan 95\% untuk masing-masing parameter.

Sementara itu, metode bootstrap yang digunakan dalam penelitian ini bersifat nonparametrik (Efron \& Tibshirani, 1993) di mana dilakukan pengambilan sampel acak dengan pengembalian yang kemudian digunakan untuk mengestimasi parameter model. Proses ini diulang sebanyak yang diperlukan dan hasil estimasi digunakan untuk menghitung tingkat galat dan membentuk selang kepercayaan untuk setiap parameter.

\section{Hasil dan Diskusi}

Data yang digunakan untuk estimasi model pertumbuhan adalah data total kasus per sejuta penduduk yang berasal dari Roser (2020). Data total kasus per sejuta penduduk digunakan karena merupakan ukuran relatif sehingga hasilnya bisa dibandingkan antar negara. Estimasi parameter dengan nonlinear least squares dilakukan menggunakan paket grofit dari perangkat lunak statistik R. Hasil parameterisasi untuk data Taiwan dalam rentang waktu 20 Januari - 18 Juni 2020 menunjukkan bahwa keempat model sesuai (lihat Tabel 1). 
Tabel 1. Hasil parameterisasi model pertumbuhan dengan data Taiwan

\begin{tabular}{|c|c|c|c|c|}
\hline \multirow{2}{*}{ Par. } & \multicolumn{4}{|c|}{ Model } \\
\cline { 2 - 5 } & Logistik & Richards & $\begin{array}{c}\mathbf{m .} \\
\text { Gomp }\end{array}$ & $\begin{array}{c}\text { e. } \\
\text { Gomp }\end{array}$ \\
\hline$A$ & 18,40 & 18,36 & 18,54 & 16,31 \\
\hline$\mu$ & 0,63 & 0,63 & 0,69 & 0,77 \\
\hline$\lambda$ & 51,31 & 51,54 & 51,87 & 55,03 \\
\hline$v, \alpha$ & & 1,31 & & 0,0088 \\
\hline$t_{s}$ & & & & 356,10 \\
\hline $\mathrm{JKR}^{*}$ & 43,78 & 42,95 & 59,69 & 18,80 \\
\hline
\end{tabular}

* Jumlah kuadrat residual

Dari semua model tersebut yang paling sesuai dengan data adalah model expanded Gompertz. Ini ditunjukkan dengan nilai jumlah kuadrat residual (JKR) terkecil, yaitu 18,80.

Karena data Taiwan sesuai dengan keempat model, semua model tersebut dicoba untuk merepresentasikan data Indonesia. Walaupun Indonesia belum mengalami semua fase dalam kurva pertumbuhan, namun diyakini pada akhirnya itu akan terjadi. Ketika hal tersebut terjadi, dinamikanya akan memiliki kesesuaian terbaik dengan salah satu dari keempat model pertumbuhan tersebut.

Dari hasil estimasi menggunakan nonlinear least squares didapati hanya dua model yang sesuai dengan data Indonesia, yaitu logistik dan modified Gompertz. Proses optimasi untuk mendapatkan estimasi parameter model Richards dan expanded Gompertz tidak menghasilkan solusi. Ini berarti kedua model tersebut tidak berkesesuaian dengan data Indonesia. Hasil estimasi untuk data Indonesia dapat dilihat dalam Tabel 2.

Tabel 2. Hasil parameterisasi model pertumbuhan dengan data Indonesia

\begin{tabular}{|c|c|c|}
\hline \multirow{2}{*}{ Par. } & \multicolumn{2}{|c|}{ Model } \\
\cline { 2 - 3 } & Logistik & Modified Gompertz \\
\hline$A$ & 233.73 & 678.31 \\
\hline$\mu$ & 2.77 & 3.44 \\
\hline$\lambda$ & 50.32 & 61.34 \\
\hline JKR $^{*}$ & 911.70 & 398.80 \\
\hline
\end{tabular}

* Jumlah kuadrat residual

Dalam Tabel 2 terlihat bahwa model modified Gompertz lebih sesuai dengan data Indonesia dibanding model logistik. Dilihat dari nilai JKR, kesesuaian model dengan data Taiwan lebih baik dibanding data Indonesia. Model modified Gompertz yang merupakan model dengan kesesuaian paling rendah untuk data Taiwan ternyata memiliki kesesuaian paling baik untuk data Indonesia. Hasil ini bersyarat terhadap kualitas data yang ada. Data Taiwan relatif lebih stabil karena didasarkan pada rasio tes yang lebih tinggi dan manajemen pandemi yang lebih baik. Selain itu, data Taiwan lebih komprehensif, dalam arti telah melewati fase pertumbuhan secara lengkap dari fase awal pertumbuhan sampai dengan fase jenuh. Seiring dengan waktu, jika keempat model pertumbuhan tersebut diparameterisasi menggunakan data yang lebih baru, bisa jadi modified Gompertz bukan lagi model yang paling sesuai. Selain itu, data yang lebih baru diyakini akan menghasilkan model dengan JKR yang lebih rendah.

Hal yang menarik dari hasil estimasi di Tabel 2 adalah perbedaan yang signifikan dalam nilai parameter $A$. Dalam penelitian ini, parameter $A$ merepresentasikan level tertinggi total kasus per sejuta penduduk yang akan terjadi. Model logistik memprediksi bahwa kurva COVID-19 akan melandai di level 233,73, sementara menurut model modified Gompertz di level 678,31. Per 18 Juni 2020, total kasus per sejuta penduduk Indonesia ada di level 151,47 .

Nilai estimasi parameter $A$ Indonesia jauh lebih tinggi dibanding Taiwan yang ada di kisaran 18. Taiwan merupakan negara yang memiliki persiapan paling baik dalam menghadapi pandemi COVID-19 (Moore, 2020). Selain itu, Taiwan memiliki sistem kesehatan yang unggul. Kedua hal tersebut membuat mereka berhasil mengatasi COVID-19 dengan total kasus yang sangat rendah.

Hasil estimasi berdasarkan model logistik dan modified Gompertz kemudian digunakan untuk memprediksi akhir pandemi COVID-19 di Indonesia. Untuk itu diperlukan informasi mengenai sebaran nilai parameter model. Tabel 3 menampilkan simpangan baku setiap parameter dari kedua model yang diperoleh dari hasil cross validation dan bootstrapping.

Tabel 3. Simpangan baku parameter model pertumbuhan terpilih

\begin{tabular}{|c|c|c|}
\hline \multirow{2}{*}{ Parameter } & \multicolumn{2}{|c|}{$\begin{array}{c}\text { Simpangan baku parameter } \\
\text { model }\end{array}$} \\
\cline { 2 - 3 } & Logistik & $\begin{array}{c}\text { Modified } \\
\text { Gompertz }\end{array}$ \\
\hline$A$ & 11.21 & 68.35 \\
\hline$\mu$ & 0.07 & 0.20 \\
\hline$\lambda$ & 1.08 & 2.76 \\
\hline
\end{tabular}


Dalam Tabel 3 dapat dilihat bahwa simpangan baku relatif besar untuk parameter $A$. Model logistik memberi estimasi nilai parameter $A$ yang lebih akurat dengan simpangan baku 11,21 yang ekuivalen dengan koefisien variasi 0,05 , sedangkan model modified Gompertz memiliki koefisien variasi 0,10 .

Berdasarkan informasi sebaran data di Tabel 3 selanjutnya dilakukan simulasi untuk memprediksi akhir pandemi. Karena tidak ada kriteria definitif mengenai akhir pandemi, dalam penelitian ini ditentukan bahwa pandemi dianggap berakhir ketika banyaknya kasus baru per sejuta penduduk kurang dari 0,1 . Kriteria ini ditentukan berdasarkan kondisi yang dicapai oleh Taiwan.

Simulasi dilakukan dengan membangkitkan nilai parameter model berdasarkan nilai parameter hasil estimasi least squares. Dalam simulasi, semua parameter diasumsikan mengikuti distribusi normal. Banyaknya replikasi ditentukan menggunakan prosedur fixed sample size (Law, 2015) dengan relative error $1 \%$ dan tingkat signifikansi $5 \%$ diperoleh ukuran sampel yang dibutuhkan sebesar 64 untuk model logistik dan 474 untuk model modified Gompertz. Tabel 4 menampilkan prediksi akhir pandemi berdasarkan hasil simulasi.

Tabel 4. Prediksi akhir pandemi berdasarkan model pertumbuhan terpilih

\begin{tabular}{|l|c|c|}
\cline { 2 - 3 } \multicolumn{1}{c|}{} & \multicolumn{2}{c|}{ Hari pandemi berakhir } \\
\cline { 2 - 3 } \multicolumn{1}{c|}{} & Logistik & $\begin{array}{c}\text { Modified } \\
\text { Gompertz }\end{array}$ \\
\hline Rerata & 193 & 464 \\
\hline $95 \% \mathrm{Cl}-\mathrm{LB}$ & 180 & 375 \\
\hline $95 \% \mathrm{Cl}-\mathrm{UB}$ & 206 & 555 \\
\hline
\end{tabular}

Prediksi hari pandemi berakhir dalam Tabel 4 dihitung dari pertama kali kasus terjadi yaitu 2 Maret 2020. Tabel 5 menampilkan rentang 95\% prediksi tanggal pandemi berakhir berdasarkan kedua model.

Tabel 5. Prediksi tanggal pandemi berakhir berdasarkan model pertumbuhan terpilih

\begin{tabular}{|l|c|c|}
\hline \multirow{2}{*}{ Model } & \multicolumn{2}{|c|}{$\begin{array}{c}\text { Prediksi tanggal akhir } \\
\text { pandemi }\end{array}$} \\
\cline { 2 - 3 } & Optimis & Pesimis \\
\hline Logistik & $28 / 8 / 2020$ & $23 / 9 / 2020$ \\
\hline Modified Gompertz & $9 / 3 / 2021$ & $7 / 9 / 2021$ \\
\hline
\end{tabular}

Gambar 1 menampilkan selang kepercayaan untuk total kasus per sejuta penduduk. Pertumbuhan total kasus per sejuta penduduk akan jatuh dalam interval di Gambar 1 dengan probabilitas $95 \%$.

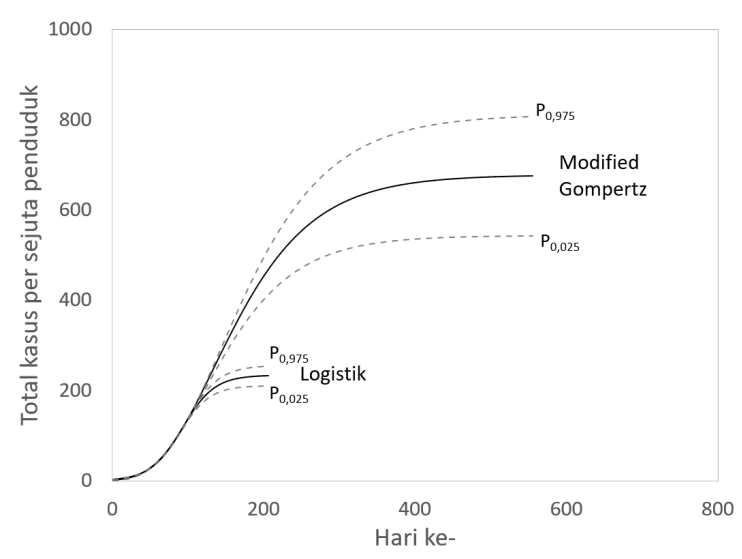

Gambar 1. Selang kepercayaan 95\% prediksi akhir pandemi

Prediksi di Tabel 5 dan Gambar 1 harus diinterpretasikan dengan hati-hati. Hasil parameterisasi model dengan data Indonesia (lihat Tabel 2) memiliki JKR yang jauh lebih besar dibanding Taiwan. Ini bisa jadi disebabkan akurasi data yang relatif rendah. Banyak faktor yang bisa mempengaruhi akurasi data, seperti intensitas pembatasan sosial yang dilakukan, kecepatan pelacakan, dan banyaknya tes yang dilakukan. Per 18 Juni 2020, rasio tes per sejuta penduduk Taiwan 3.136. Selain itu, Taiwan melakukan pembatasan sosial yang ketat sejak pertama kali pandemi terjadi di Wuhan serta memiliki sistem kesehatan yang sangat baik. Dengan rasio tes Indonesia per 18 Juni 2020 hanya 1.311, pembatasan sosial yang relatif longgar, dan sistem kesehatan yang tidak sebaik Taiwan, data Indonesia mengandung ketidakpastian yang sangat besar. Ini berarti prediksi di Tabel 5 bisa jadi tidak akurat.

Prediksi di Tabel 5 tidak dimaksudkan sebagai luaran dari one-shot model. Dengan berjalannya waktu akan semakin banyak tes yang dilakukan dan diharapkan semakin baik kualitas penanganan pandemi, sehingga kualitas data juga semakin baik. Jika data sudah terkumpul dalam jumlah yang memadai, bisa dilakukan parameterisasi model lagi sehingga bisa diperoleh prediksi yang lebih akurat.

\section{Kesimpulan}

Dalam penelitian ini, empat model 
pertumbuhan parametrik digunakan untuk merepresentasikan pertumbuhan total kasus COVID-19 per sejuta penduduk di Indonesia. Dari proses estimasi menggunakan nonlinear least squares didapati bahwa dua model pertumbuhan sesuai dengan data Indonesia, yaitu model logistik dan modified Gompertz, di mana model modified Gompertz memiliki kesesuaian yang lebih baik.

Berdasarkan estimasi parameter model pertumbuhan, dilakukan simulasi untuk memprediksi akhir pandemi di mana akhir pandemi ditandai dengan angka kasus baru per sejuta penduduk yang lebih kecil dari 0,1. Dari hasil simulasi, menurut model modified Gompertz, pandemi akan berakhir antara 9 Maret - 7 September 2021 pada level total kasus per sejuta penduduk antara 206 sampai dengan 555. Sementara itu, menurut model logistik, pandemi akan berakhir antara 28 Agustus - 23 September 2020 pada level total kasus per sejuta penduduk antara 180 sampai 375.

Penelitian ini dapat dikembangkan lebih lanjut dengan membuat skenario-skenario pertumbuhan berdasarkan perbandingan ukuran relatif dengan Taiwan yang merupakan negara yang telah mengalami setiap tahap dalam fase pertumbuhan. Ukuran yang digunakan bisa berupa rasio tes, intensitas pembatasan sosial, dan ukuran lain yang bisa merepresentasikan kualitas penanganan pandemi.

\section{Daftar Pustaka}

Bates, D. M. \& Chambers, J. M. (1991). Nonlinear Models. Dalam J. M. Chambers dan T. J. Hastie: Statistical Models in S, (421-454). London: Chapman \& Hall.

Bates, D. M. \& Watts, D.G. (2007). Nonlinear Regression Analysis and Its Applications. New York: John Wiley \& Sons.

Efron, B. \& Tibshirani, R. J. (1993) An Introduction to the Bootstrap. New York: Springer Science+Business Media Dordrecht.

Fang, Y., Nie, Y., \& Penny, M. (2020). Transmission Dynamics of the COVID-19 Outbreak and Effectiveness of Government Interventions: A Data-Driven Analysis. Journal of Medical Virology, 92, 645-659.

Halloran, M. E. (2001). Concepts of Transmission and Dynamics. Dalam J. C.
Thomas dan D. C. Weber (Ed.): Epidemiologic Methods for the Study of Infectious Diseases, (56-85). Oxford: Oxford University Press.

Kahm, M., Hasenbrink, G., Fraté, H. L., Ludwig, J., \& Kschischo, M. (2010). Grofit: Fitting Biological Growth Curves with R. Journal of Statistical Software, 33. 1-31.

Kermack, W. \& McKendrick, A. (1927). Contributions to the Mathematical Theory of Epidemics. Proceedings of the Royal Society, 115A, 700-721.

Law. A. (2015). Simulation Modeling and Analysis (5th ed.). New York: McGraw-Hill Education.

Moore, C., How a Nation with the Same Population as Australia Dodged Coronavirus Almost Entirely - and not Trusting Their Giant Neighbour China was Step One, [Online], Diakses dari: https://www.dailymail.co.uk/news/article8213351/How-Taiwan-beatcoronavirus.html, [2020, 19 Juni].

Nuraini, N., Khairudin, K., \& Apri, M. (2020). Modeling Simulation of COVID-19 in Indonesia Based on Early Endemic Data. Communication in Biomathematical Sciences, 3, 1-8.

Richards, F. J. (1959). A Flexible Growth Function for Empirical Use. Journal of Experimental Botany, 10. 290-300.

Roser, M. (2020). Coronavirus Pandemic Country Comparisons, [Online], Diakses dari: https://ourworldindata.org/coronaviruscountry-comparisons, [2020, 19 Juni].

Shen, C. Y. (2020). Logistic Growth Modelling of COVID-19 Proliferation in China and its International Implications. International Journal of Infectious Diseases, 96, 582-589.

Vega, D. I. (2020). Lockdown, One, Two, None, or Smart: Modeling Containing COVID-19 Infection: A Conceptual Model. Science of the Total Environment, 730, 1-5.

Zwietering, M. H., Jongenburger, I., Rombouts, F. M., \& Riet, K. v. (1990). Modeling of the Bacterial Growth Curve. Applied and Environmental Microbiology, 56. 1875-1881. 